\title{
Recent developments in seed production in Oregon, U.S.A.
}

\author{
M. Phitip Rolston \\ Grasslands Division, DSIR, Palmerston North
}

ABSTRACT. Developments in weed control include the use of activated carbon applied in bands to protect the emerging grass seed crop from soil-applied herbicides. "Weed-seed free" crops can be produced with this technique, especially when combined with chcmical seedbed treatments. Novel techniques of herbicide usage, including the roller herbicide applicator, are being used for weed control. Field burning is important for disease control and techniques of smoke management are improving. Aerial inspections of seed crops by seed certification inspectors are faster and are considered to be as thorough as ground inspections. Seed growers can be classified as either high- or low-cost producers. Fixed costs show economies of scale until farm size reaches 250 to 300 ha. Operating costs are similar for all types of seed crops, with fertilizer, herbicides and machinery costs representing up to $50 \%$ of total costs.

Key words: Herbage seed production, Oregon, activated carbon, ficld burning, aerial inspections.

\section{INTRODUCTION}

Oregon is the major producer of forage and turf grass species in the U.S.A. Herbage seed crops are the fourth-ranked crop in Oregon, with a value of about $\$ 70$ million. Within Oregon, much of the grass seed production is confined to the Willamette River basin, where 100000 ha produce nearly all of the U.S. grown annual and perennial ryegrass, 90 to $97 \%$ of the fine fescue (Fesiluca spp.) and browntop (Agrostis spp.), 40 to $50 \%$ of the cocksfoot (Dactylis glomerata L.), and 10 to $25 \%$ of the Kentucky bluegrass (Poa pratensis L.) and tall fescue (Festuca arundinucea Schreb.) seed (Conklin and Fisher, 1973). Legume seed production is of lesser importance, with red clover (Trifolium pratense L.), crimson clover (T. incarnafurn L.) and hairy vetch (Vicia villosa Roth.) being important in the Willamette Valley and lucerne (Medicago sativa L.) in eastern Oregon.

The climate of the Willamette Valley is Mediterranean, with hot, dry summers, and cool, wet, overcast winters (Table 1).

Oregon seed production practice is of interest to New Zealand because of the high average seed yields achieved (Table 2).

\section{WEED CONTROL}

\section{CARbon Band NG}

The production of "weed-seed free" cultivars required for the turf grass industry has become possible with the development of the carbon banding technique (Lee, 1973, 1978). In Oregon, 6000 ha of grass seed are established annually using activated carbon slurries that are sprayed in bands, $2.5 \mathrm{~cm}$ wide, above the seed row at planting. With row spacings of 35 $\mathrm{cm}, 22 \mathrm{~kg}$ of activated carbon/ha is used. Be-

TABLE 1: AVERAGE CLIMATE DATA FOR CQRVALLIS, WILLAMETTE VALLEY, OKEGON AND LINCOLN, CANTERBURY'

\begin{tabular}{|c|c|c|c|c|}
\hline & \multicolumn{2}{|c|}{ Summer' } & \multicolumn{2}{|c|}{ Winter ${ }^{2}$} \\
\hline & Corvallis & Lincoln & Corvallis & Lincoln \\
\hline Temperature $\left({ }^{\circ} \mathrm{C}\right)$ & & & & \\
\hline Maximum & 27 & 22 & 10 & 12 \\
\hline Minimum & 10 & 11 & 2 & 3 \\
\hline Rainfall total & & & & \\
\hline $\begin{array}{l}(\mathrm{mm}) \\
\text { Relative humidity, }\end{array}$ & 22 & 112 & 720 & 294 \\
\hline$(\%)$ & 46 & 65 & 83 & 82 \\
\hline $\begin{array}{l}\text { Radiation }- \text { daily } \\
\text { (Langleys) }\end{array}$ & 549 & 504 & 132 & 182 \\
\hline
\end{tabular}

1 Sources: Bates and Calhoun, 1976; N.Z. Meterological Service.

'Summer values are for the 2 months of July-August for Corvallis and January-February for Lincoln. Winter values are for the 5-month period NovemberMarch for Corvallis. and May-September for Lincoln. 'Relative humidity recorded at $10 \mathrm{a} . \mathrm{m}$. for Corvalis and 9 a.m. for Lincoln. 
TABLE 2: AVERAGE HERBAGE SEED YIELDS FOR OREGON'

\begin{tabular}{lcc}
\hline crop & Years & $\begin{array}{c}\text { Seed Yield } \\
(\mathrm{kg} / \mathrm{ha})\end{array}$ \\
\cline { 2 - 3 } Annual ryegrass & $1973-76$ & 1480 \\
Perennial ryegrass & $1973-76$ & 840 \\
Cocksfoot & $1975-76$ & 780 \\
Tall fescue & $1971-76$ & 750 \\
Chewings fescue & $1970-76$ & 540 \\
Browntop & $1972-76$ & $\mathbf{3 5 0}$ \\
Red clover & $1972-76$ & $\mathbf{2 8 0}$
\end{tabular}

1 Sources: Oregon Commodity Data Sheets, Oregon State University Extension Service, and Oregon Crop and Livestock reporting service, United States Department of Agriculture, Statistical Reporting Service.

fore the crop emerges, the herbicide diuron is applied at 2.6 to $3.3 \mathrm{~kg} / \mathrm{ha}$. This herbicide is lethal to a wide range of germinating species including many grasses and legumes. Activated carbon adsorbs and inactivates the herbicide, giving a narrow band of protection above the seed row. Grass weed species that germinate within the band are controlled with ethofumesate. The activated carbon banding technique has a potential use in legume seed production (Rolston et al., 1979), particularly in combination with chemical seedbed treatments to control contamination by volunteer legumes (Table 3).

\section{Chemical Seedbed}

If the seedbed has been prepared before winter for spring sowings, or even for several weeks before planting, or when slow-emerging species are used, paraquat is applied in the period from immediately before planting until $5 \%$ crop emergence, to remove weed species that have germinated before the crop. The philosophy is to avoid disturbing the seedbed and thereby encourage germination of buried seed with further cultivation. When used with carbon banding the chemical seedbed gives outstanding weed control results.

\section{Post-harvest Treatments}

The control of volunteer crop seedlings and weeds in perennial grasses is achieved by burning or removing stubble after harvest and spraying in early winter with atrazine in ryegrass crops and diuron in other grass seed crops. These herbicides arc photosynthetic inhibitors and have low water solubilities. Their successful use is dependent on adequate rainfall to wash the herbicide off leaves into the soil. Only shallow-rooting, newly germinated weeds have roots in the herbicide zone. These herbicides may not work as well in New Zealand seed crops because of our lower winter rainfall, higher winter light intensities and higher crganic matter $(>5 \%)$ soils than those in Oregon. Light rains in early autumn may nerminate many weed species before conditions are suitable for the use of atrazine or diuron. When this situation occurs, propham or chlorpropham are used to control many germinating species, particularly grasses. Perennial legume stands over 6 months old are sprayed with paraquat in early to mid winter. With red clover, diuron is also applied to give broad spectrum residual weed control.

TABLE 3: VOLUNTEER LOTUS TENUIS COUNTS IN A CHEMICAL SEEDBED ALONE AND WITH ACTIVATED CARBON BANDING PLUS DIURON TREATMENT (ROLSTON ET AL., 1979)

\begin{tabular}{|c|c|c|c|c|}
\hline $\begin{array}{c}\text { Chemical Seedbed } \\
\text { Herbicides }\end{array}$ & $\begin{array}{c}\text { Rate } \\
(k g / h a)\end{array}$ & $\begin{array}{c}\text { Application } \\
\text { (days before seeding) }\end{array}$ & $\begin{array}{l}\text { Chemical } \\
\text { Seedbed } \\
\text { (vo }\end{array}$ & $\begin{array}{l}\text { Chemical Seedbed } \\
+ \text { Carbon Banding } \\
\text { ers } /\left(10 \mathrm{~m}^{2}\right)^{1}\end{array}$ \\
\hline $\begin{array}{l}\text { Paraquat }+ \\
\text { Paraquat }\end{array}$ & $\begin{array}{l}0.80 \\
\mathbf{0 . 2 8}\end{array}$ & 105 & 10 & 0 \\
\hline Glyphosate & 0.28 & 30 & 90 & 1.2 \\
\hline Glyphosate & 0.41 & 30 & 74 & 0.2 \\
\hline Glyphosate & 0.55 & 30 & 70 & 0 \\
\hline Glyphosate & 0.83 & 30 & 52 & 0 \\
\hline Glyphosate & 1.11 & 30 & 37 & 0 \\
\hline
\end{tabular}

'Counts made 9 months after treatments. OECD regulations allow one contaminant per $10 \mathbf{m}^{2}$. 


\section{WiLd oAt Control}

Wild oat (Avena fatua L.) is a greater problem during establishment (than in established crops), particularly when grass seed crops follow cereal crops. The primary tool for control is MSMA (monosodium methanearsonate), applied at $6 \mathrm{~kg} / \mathrm{ha}$ plus wetting agent, while ethofumesate is being used in ryegrass. In established grasses, atrazine gives better control of autumn-germinating wild oats than does simazine, propham or chlorpropham. Spring applications of MSMA may also be required, particularly with propham and chlorpropham as the residual soil life of these products is short.

\section{Chemical Roguing}

Herbage seed fields are commonly rogued in early spring by spot spraying weeds and offtypes with glyphosate. Crews of up to six people, with hand guns and 10 to $20 \mathrm{~m}$ of hose, operate in a systematic manner in front of a slow-moving tractor that is carrying the herbicide.

\section{Noved TECHNIOUES}

The developments of novel techniques in weed control (Rolston. 1979) has resulted in benefits for herbage seed growers in the United States. Equipment capable of applying herbicides to weeds that are taller than the crop is being used, particularly the roller applicator developed by Wyse and Habstritt (1977) for the control of couch (Agropyron repens (L.) Beauv.) and Phalaris arundinacea L. in Kentucky bluegrass seed crops. A revolving, carpetcovered drum (25 to $35 \mathrm{~cm}$ in diameter) saturated with glyphosate wipes herbicides on to the weeds. Growers arc converting windrowers and combines to make roller applicators by replacing the reel with a carpet-covered drum. The rope-wick applicator (Dale, 1979) represents a low-cost alternative. It consists of $75 \mathrm{~mm}$ diameter PVC pipe with numerous pieces of $13 \mathrm{~mm}$ diameter ropes, $30 \mathrm{~cm}$ long, stretched horizontally along the front of the pipe. The ropes act as wicks, drawing the herbicide from the pipe. By pushing the applicator over weeds taller than the crop, a lethal dose of herbicide can be applied. In recent ex- periments Californian thistle (Cirsium arvense (L.) Scop.) has been controlled in white clover seed crops with this equipment.

\section{DISEASE CONTROL}

Rust diseases, especially stem rust (Puccinia graminis Pers.) in perennial ryegrass (Lolium perenne L.), cause serious losses, while other grass rusts are also troublesome. Control of grass rusts has been difficult even with multiple applications of the standard fungicide maneb + nickel sulphate. Environmental officials have expressed concern at the excessive use of nickel products and the feeding of nickel-contaminated straw to livestock. In recent trials, split applications of the systemic fungicide triadimefon $(0.75+0.75 \mathrm{~kg} / \mathrm{ha})$ have increased yields of perennial ryegrass from less than $160 \mathrm{~kg} / \mathrm{ha}$ in untreated plots to greater than $1500 \mathrm{~kg} / \mathrm{ha}$, compared with $880 \mathrm{~kg} / \mathrm{ha}$ for the standard treatment (Hardison, 1977).

\section{FIELD BURNING AND SMOKE MANAGEMENT}

Post-harvest burning of straw and stubble in grass fields is common in the production of perennial ryegrass, cocksfoot, and fescue seed crops. Burning was initiated in the 1940s as a cultural practice for the control of numerous diseases including blind-seed disease, ergot and grass seed nematode. Additional advantages included improved weed control by removal of crop residues that interfere with the activity of soil-applied herbicides, thermal destruction of weed seeds and insect pests on the soil surface and in straw, disposal of straw residues, and increased fertilizer efficiency (Hardison, 1964). In the absence of burning, seed yields decline with increasing stand age. Burning appears to develop a juvenile stand characteristic that maintains the high seed yield of the first year.

Smoke plumes in late summer are obvious and an easily identifiable source of air pollution. Annual burning of up to 124000 ha of grass seed and cereal stubble occurred in the Willamette Valley during the 1960s. Temperature inversions and winds accentuated smoke concentrations in metropolitan areas, resulting in public regulatory burning controls in 1969 and legislation to phase out field burning 
by 1975 (Conklin and Bradshaw, 1979). This legislation was subsequently amended, with a considerable reduction in the area that could be burnt. Cereal stubble burning is banned in the Willamette Valley. A burning permit cost, in $1979, \$ 2.50 /$ ha for registration to bum, plus $\$ 6.25 /$ ha for the area actually burned. Money from burning fees as well as state funds are used for research, including studies on the utilization of crop residues, development of alternative crops, improvement of smoke management, alternative methods of field sanitation, alternative pest control methods, and health effects of open field burning.

Initially research was aimed at the development of an acceptable mobile field sanitizer and at straw removal methods. Mobile burning machines, which gave a controlled bum within a fire-box reducing most of the apparent smoke emissions, were built at a cost of $\$ 20000$ to $\$ 40000$ each. They were effective at simulating the effects of burning, but problems of slow operating speeds, operator safety, smoke emissions and metal fatigue were not solved. Straw must be removed before the mobile field sanitizer can operate. Research work on possible methods of utilizing straw includes chemical treatments to improve dipestibilitv for animal feed, and conversion to pellets, cubes or high-density bales for export to Tapan as animal feed, mulches for use in hvdro-sealing of roadside cuttings, paper and fibreboard products, as a heating fuel, or for methanol conversion by fermentation. The cost of collecting and transporting straw residues from the field to the processing plant may limit the development of alternative methods for straw utilization. Techniques of starting bums that improve the "lifting" of smoke include firing from the centre rather than the perimeter, and rapid ignition of large areas using helicopters.

Smoke management research has been particularly successful in balancing the area to be burnt with suitable meteorological conditions. The State of Oregon has recognized that under a smoke management programme, open burning does not significantly increase the pollution problems of metropolitan areas. As a result, a state law has been passed that would allow up to 112000 ha to be burned in 1980 and after, under a restrictive smoke management programme. Under average environmental conditions, growers will probably burn 60000 to 70000 ha annually. However, the Federal Government's Environmental Protection Agency has tried (unsuccessfully) to set a limit of 20000 ha for burning. The field burning controversy will continue to smoulder.

\section{SEED CERTIFICATION}

\section{Pre-haRVEST InsPectuons}

In recent years aerial inspections by helicopter have become important in Oregon. This procedure was initiated on a small scale with browntop (bentgrass) in 1971. In 1979, 30000 ha were aerially inspected, representing 770 fields, requiring 24.2 hours' Aying time. In comparison, ground inspectors cover 12 to 15 fields per day. Crops inspected include annual and perennial ryegrasses, cocksfoot, tall fescue, bluegrass, fine fescue, browntop and white clover. Usually, the runners of the helicopter are just above the crop. A low speed, sufficient to keep just ahead of the propwash, is used. Fields that cause doubts in the mind of the individual making the aerial inspections are marked for ground inspection. All Foundation (breeders') fields are examined both from the air and from the ground.

Aerial inspections are considered to be just as thorough, or more so, than ground inspections. Far more of a field can be seen, the isolation is verified more readily, and the uniformity of maturity is very discernible.

\section{SeEding Inspections}

Seedling inspections are made on all perennial grasses. annual ryegrass and perennial legumes, and are considered important in maintaining genetic purity. Applications for seedling inspections are submitted by the grower within 60 days after seeding, and must include all of the stock seed tags from seed used for the planting.. Rejection from certification will occur if volunteers are detected during the seedling inspection.

\section{WAREHOUSE INSPECTIONS}

There are over 300 seed cleaning plants in Oregon, with many growers cleaning their own 
seed. All warehouses cleaning or blending seed eligible for Oregon certification are inspected and approved each year. Evidence of facilities and records to adequately maintain identity and separation of cultivars are required. A warehouse can be prevented from cleaning certified seed if there is evidence of physical contamination of cultivars.

\section{ECONOMICS}

The economics of seed production in Oregon have been studied by Conklin and associates. In one study Conklin and Fisher (1973) found that farms producing the same seed type could be classified as high-cost and low-cost types. Factors which contributed to large cost differences between farms producing the same seed type were diverse. However, fertilizer, chemical and machine costs were the most important contributors to total production costs (generally over $50 \%$ ), and attempts to reduce production costs ought to include an evaluation of those costs. For some growers, increased usage of fertilizers and chemicals was directly correlated with higher yields. For others, the relationship was inverse.

Production costs per hectare between species showed less variability than within species. This result reflects similar cultural and managerial practices used across all grass seed types. Average profits per hectare, in descending order for grass types, were: cocksfoot, Kentucky bluegrass, fine fescue, tall fescue, perennial ryegrass, annual ryegrass. Since production costs are similar, differences in profit between seed types are due to differences in return, a function of price and yield. Price differences were the largest contributor to profit differences between seed types.

Farms that had less than $40 \%$ of farm sales generated by grass seed production had average operating costs double those of farms where grass seed was more important, Operating costs were independent of farm size. However, fixed costs (i.e., those costs which a farm incurs regardless of the level of production), including depreciation, interest, insurance, and opportunity costs for owner's labour and capital valuc of land, declined rapidly with increasing farm size, until 250 to 300 ha was achieved. Economies of scale in grass seed production therefore exist. But fixed costs are variable, ranging from 30 to $95 \%$ of total costs for farms 120 ha or smaller, and from 20 to $90 \%$ for 120 to 300 ha farms. Thus it is not assured that individuals who aim to decrease average lotal costs will achieve this goal simply by expanding farm size.

A number of cultivars are grown under contract, particularly turf type grasses, and overseas cultivars. Because of large price fluctuations of non-contract public cultivars, particularly annual ryegrass, some growers have used on-farm storage to withhold seed from the market in years of low price, and sold later in years of high price. Regular monitoring of seed germination is required for this strategy.

\section{CONCLUSION}

In looking at recent developments in seed production in Oregon we need to ask the question, why are their growers achieving high average seed yields? Some reasons would include a specialist approach by growers, not that animals are excluded from seed-producing farms. Many growers use store lambs for grazing grass seed fields during winter months. There is considerable research and extension effort, both state and federally funded, in seed production in Oregon. There is at least one fulltime equivalent in each of the following areas: weeds, diseases, insect pests, pollination, physiology, production practice, harvesting and processing, straw utilization, and economics.

However, the adoption in New Zealand of existing and recently developed production practices from Oregon, particularly fertilizer and herbicide practices, must be made with caution. Consideration should be given to factors such as climate that are the cause of or allow certain production practices to be undertaken. We can learn from Oregon, but research is needed to modify developments into systems appropriate to our own environmental situations and cultivars in New Zealand.

\section{ACKNOWLEDGEMENTS}

To Dr H. Youngberg, D. Brewer, Extension Department, and Dr W. 0. Lee, USDA, Crop Science Department, Oregon State University, Corvallis, Oregon, for information provided for this paper. 


\section{REFERENCES}

Bates, E. M.; Calhoun, W., 1976. Special Report 277, Agricultural Experimental Station, Oregon State University, Corvallis.

Conklin, F. S.; Bradshaw, R. C., 1979. Circular of Information 675, Agricultural Experimental Station, Oregon State University, Corvallis

Conklin, F. S.; Fisher, D. E., 1973. Ibid., 643.

Dale. J. E., 1979. 3rl Cotton Weed Sci.Rrs. Conf.: In press.
Hardison, I. R.. 1964. Proc. Ann. Mtg O regon Seed Crow ers League, 24: 93-6.

1977. Ibid., 37: 23-5.

Lee, W. O.. 1973. Weed Sci., 21: 537-41.

1978. Ibid., 26: 675-8.

Rolston, M. P., 1979. Pror. N.Z. Weed \& Pest Con trol Conj.. 32: 202-6.

Rolston. M. P.; Lee, W. 0.; Appleby, A. P., 1979. Agronomy $I ., 71$ (4): 665-75.

Wyse, D. L.; Habstritt, C., 1977. Proc. North Central Weed Control Con/., 32: 144-5. 